\title{
Inheritance of the Partly Colored Seedcoat Pattern, Bipunctata, in Common Bean
}

\author{
Mark J. Bassett ${ }^{1}$ \\ Horticultural Sciences Department, Institute of Food and Agricultural Sciences, University of Florida \\ Gainesville, FL 32611
}

Additional index words. Phaseolus vulgaris, inheritance

\begin{abstract}
The development of genetic tester stocks in common bean (Phaseolus vulgaris L.) for the partly colored seedcoat patterns 'bipunctata $\mathrm{BC}_{3} 5-593$ ' ( $t z$ bip) and 'virgarcus $\mathrm{BC}_{3} 5-593$ ' $(t z)$ was described. The inheritance of the bipunctata pattern was studied in the $F_{2}$ from the crosses 'bipunctata $B C_{1} 5-593$ ' $x$ 5-593 and 'bipunctata $B C_{2} 5-593$ ' $x$ 5-593. The data supported the hypothesis that a single recessive gene ( $b i p)$ converts virgarcus ( $t z$ Bip $)$ to bipunctata $(t z$ bip). The inheritance of bipunctata was also studied in the $\mathrm{F}_{2}$ from the cross 'bipunctata $\mathrm{BC}_{3}$ 5-593' $x$ 'virgarcus $\mathrm{BC}_{3}$ 5-593'. The data supported the hypothesis of complete dominance of Bip over bip in a $t z$ genetic background highly related to the recurrent parent 5-593, where only the parental phenotypes appear in the $F_{2}$.
\end{abstract}

Partly colored seedcoats in common bean (Phaseolus vulgaris) depend on the genotype $t / t$ for expression, where $T /$ - gives totally colored seedcoats (Leakey, 1988). Partly colored seedcoats have a colored zone, and the remainder of the seedcoat is white, whereas totally colored seedcoats (usually $T /$-) have no white zone that is due to $t / t$. In most genetic backgrounds, the action of $t$ produces the expansa pattern, which has only a limited area of white at the micropile end of the seed. Most of the partly colored patterns reported by Lamprecht (1940) and Schreiber (1940) are produced by the action of two genes: the $Z$ locus for zonal effects and the $L$ locus for limiter effects. Most partly colored patterns are the result of $t$ combined with one of the many possible alleles at $Z$, according

Table 1. The genetic model of Lamprecht for the partly colored seedcoat pattern, bipunctata, where all genotypes have $t / t^{\mathrm{z}}$

\begin{tabular}{lll}
\hline \hline \multicolumn{2}{c}{ Genotype } & Phenotype \\
\hline Bip & Arc & Virgarcus \\
Bip & arc & Arcus; same as virgarcus except for loss of the micropile stripe \\
bip & Arc & Virgata; same as virgarcus except for loss of the arcs on either side of the hilum \\
bip & arc & Bipunctata
\end{tabular}

${ }^{\mathrm{z}}$ Model based on analysis of $\mathrm{F}_{2}$ data from the cross Line 5 (PI 527715), bipunctata $\mathrm{x}$ Line 57, virgarcus (Lamprecht, 1940).

to the hypothesis of Schreiber (1940) and the unpublished data of M.J. Bassett. The $L$ locus has drastic constriction or erasure effects (relative to $Z$ locus effects) that result either in a very small colored zone or in a completely white seedcoat (Bassett and Blom, 1991; Schreiber, 1940)

The two most published authorities on the genetics of partly colored seeds agreed that the genotype $t z$ produces the virgarcus pattern of partly colored seedcoats, but they disagreed on the inheritance of the partly colored seedcoat pattern, bipunctata (Lamprecht, 1940; Schreiber, 1940). The results of Lamprecht (1940) led to the hypothesis that bipunctata was produced by the genotype $t z$ bip arc, where the Arc locus is also involved in the expression of the arcus and virgata patterns (Table 1). The results

Received for publication 28 Mar. 1996. Accepted for publication 26 July 1996. Florida Agricultural Experiment Station journal series R-05058. I thank Hallie Smith (formerly with the Graphics Dept., Office of Instructional Resources, Univ. of Florida) for drawing the illustrations. The cost of publishing this paper was defrayed in part by the payment of page charges. Under postal regulations, this paper therefore must be hereby marked advertisement solely to indicate this fact. ${ }^{1}$ Professor. of Schreiber (1940) supported the hypothesis that the bipunctata pattern requires only $t z$ bip.

This paper reports the results of inheritance studies of the bipunctata pattern. Only those partly colored patterns observed in the present research will be illustrated in this paper. For illustration of other partly colored patterns mentioned in discussion, see Literature Cited.

\section{Materials and Methods}

In 1985, a program was begun at Gainesville, Fla., to backcross marker genes, especially those controlling seedcoat color and color pattern, into a recurrent parent, 5-593. Line 5-593 is a Florida dry bean breeding line with determinate habit, purple flowers, and black seeds with genotype $T$ Mar $P[C$ r] D J G B VRk (Bassett, 1994). Genetic stocks ' $t$ ers ers-2 $\mathrm{BC}_{3}$ 5-593' with pure white seedcoats and ' $t$ totally colored $\mathrm{BC}_{2}$ 5-593' with unpatterned black seedcoats were developed during the investigation of the unusual genotype for white seedcoats found in 'Early Wax' (Bassett and Blom,
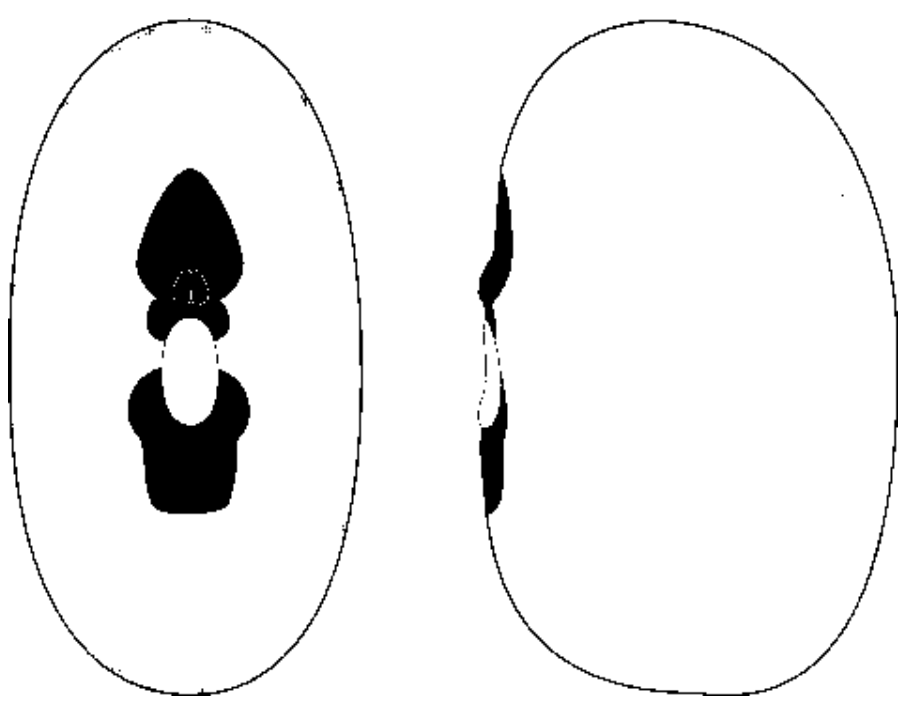

Fig. 1. A ventral view (left seed) and a side view (right seed) of the bipunctata pattern of partly colored seedcoat. 

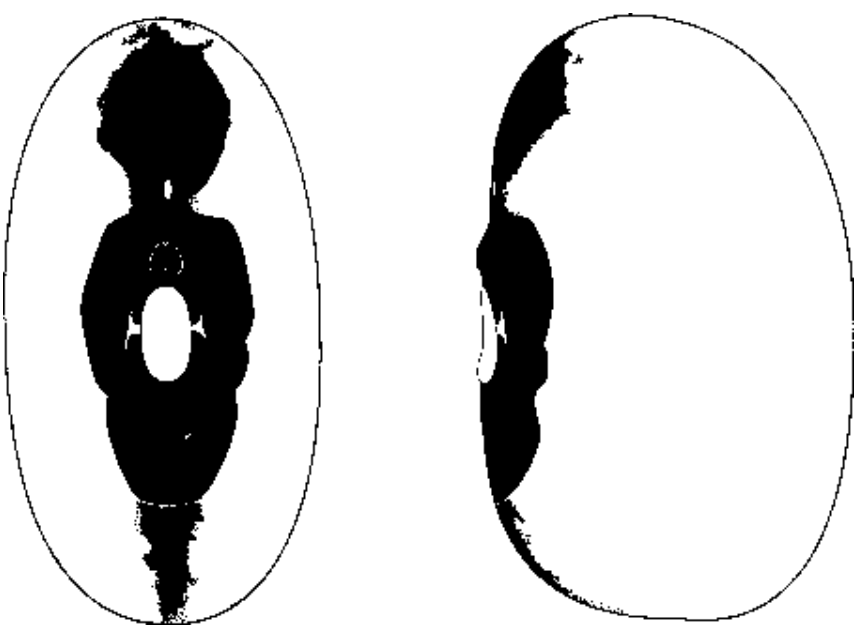

Fig. 2. A ventral view (left seed) and a side view (right seed) of the virgarcus pattern of partly colored seedcoat.
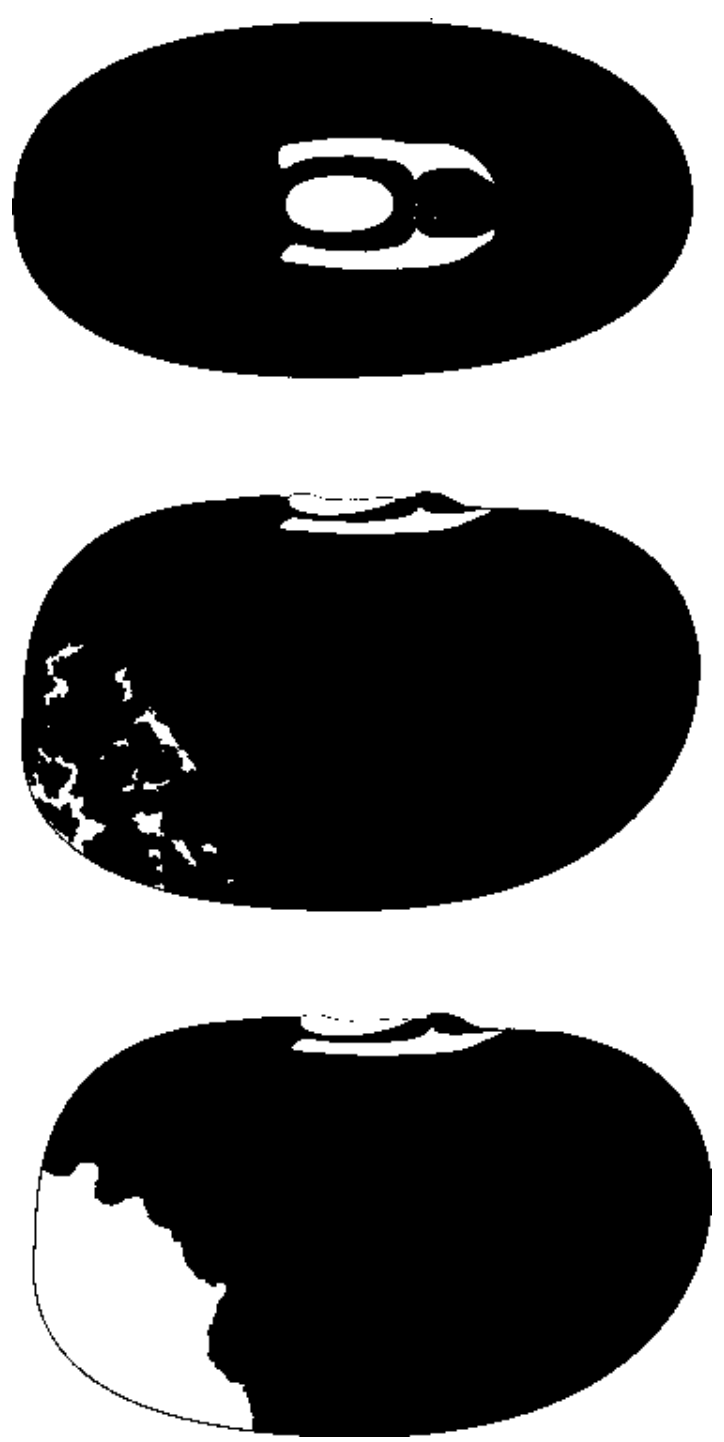

Fig. 3. Ventral view of expansa with fibula arcs (left seed), side view with minimal white area (middle seed), and side view with maximal white area for an expansa type (right seed).
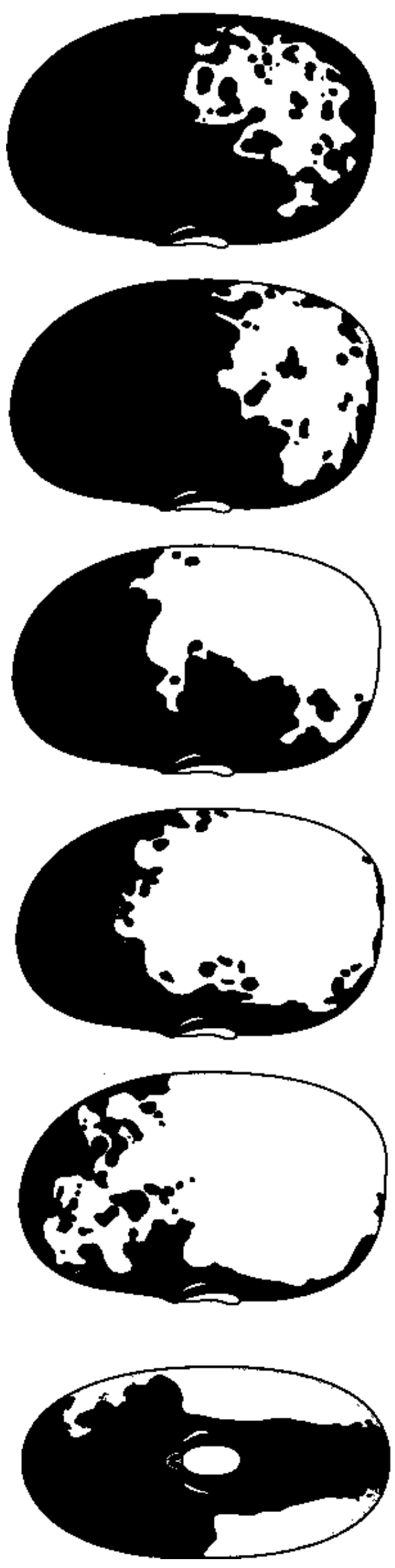

1991). The stock ' $t$ totally colored $\mathrm{BC}_{2}$ 5-593' was originally named ' $t$ selfcolored $\mathrm{BC}_{2}$ 5-593' (Bassett and Blom, 1991). The term self-colored, which is often seen in literature on partly colored seedcoats, has the same meaning as totally colored.

Line 5 of Lamprecht [now plant introduction (PI) accession 527712] was derived from 'Incomparable' and has the bipunctata pattern in black dots on white background. The bipunctata pattern is illustrated with seeds from 'bipunctata $\mathrm{BC}_{3}$ 5-593', which was derived from Line 5 during the work described below (Fig. 1).

The cross PI $527712 \times t$ ers ers- $2 \mathrm{BC}_{3} 5-593$ was made, and the $\mathrm{F}_{2}$ was planted in the field in 1991. A selection was made in the $\mathrm{F}_{2}$ for a plant with bipunctata seeds, which was found to be true breeding in a 16-plant $\mathrm{F}_{3}$ progeny test in the greenhouse. One $\mathrm{F}_{3}$ plant was selected and designated ' $\mathrm{F}_{3}$ bipunctata'. The cross ' $\mathrm{F}_{3}$ bipunctata' $\mathrm{x}$ ' $t$ totally colored $\mathrm{BC}_{2}$ 5-593' was made, and the $\mathrm{F}_{2}$ was planted in the field in 1992. Selection was made in the $\mathrm{F}_{2}$ for plants with either bipunctata or virgarcus seed patterns. A bipunctata selection found to be true breeding in a 16-plant $\mathrm{F}_{3}$ progeny test was designated 'bipunctata $\mathrm{BC}_{1}-\mathrm{F}_{3}$ 5-593'. Several virgarcus pattern selections were progeny tested in $\mathrm{F}_{4}$ plots in the field in 1993, and a virgarcus selection was made that was designated 'virgarcus $\mathrm{BC}_{1}-\mathrm{F}_{4}$ 5-593'.

The cross 'bipunctata $\mathrm{BC}_{1}-\mathrm{F}_{3}$ 5-593' x 5-593 was made and the $\mathrm{F}_{2}$ was planted in the field in 1993. Seed was harvested only

Fig. 4. A series of seeds illustrating the variation that occurs with the ambigua pattern, which is very unstable, even for a partly colored seed type, as the Latin name implies. 
Table 2. Segregation for partly colored seedcoat patterns and genotypes among $\mathrm{F}_{2}$ segregants carrying $t / t$ from two crosses: 1$)$ bipunctata $\mathrm{BC}_{1}-\mathrm{F}_{3} 5-593$ ( $t$ z bip $) \times 5-593($ T Z Bip $)$ and 2) bipunctata $\mathrm{BC}_{2}-\mathrm{F}_{3}$ 5-593 ( $t$ z bip $) \times 5-593$ (T Z Bip $)$.

\begin{tabular}{|c|c|c|c|c|c|}
\hline \multicolumn{4}{|c|}{ Seedcoat pattern classes } & \multirow[b]{2}{*}{$\chi^{2}$} & \multirow[b]{3}{*}{$P$} \\
\hline Cross & $\begin{array}{c}\text { Totally colored, } \\
\text { expansa, } \\
\text { ambigua }^{z}\end{array}$ & Virgarcus & Bipunctata & & \\
\hline no. & $t Z /--/-$ & $t z$ Bip/- & tz bip & $12: 3: 1$ & \\
\hline 1 & 221 & 56 & 19 & 0.023 & 0.99 \\
\hline $2^{\mathrm{y}}$ & 97 & 19 & 5 & 1.898 & 0.39 \\
\hline Total & 318 & 75 & 24 & 0.381 & 0.83 \\
\hline
\end{tabular}

zThe totally colored segregants are known to carry $t / t$ because of their white flowers (vs. purple flowers for $T /$-).

'Data were taken on the number of segregants with purple flowers and unpatterned black seeds, viz., 408. For the data 408, 97 , 19 and 5 the $\chi^{2}(48: 12: 3: 1)=3.013, P=0.39$.

from $\mathrm{F}_{2}$ segregants with white flowers, and data were taken on seedcoat pattern. Selection was made in the $\mathrm{F}_{2}$ for a plant with bipunctata seeds, which was found to be true breeding in a 16-plant $\mathrm{F}_{3}$ progeny test and designated 'bipunctata $\mathrm{BC}_{2}-\mathrm{F}_{3} 5-593$ '.

The cross 'bipunctata $\mathrm{BC}_{2}-\mathrm{F}_{3} 5-593$ ' $\times$ 5-593 was made, and the $\mathrm{F}_{2}$ was planted in the field in 1994. Data were taken on the $\mathrm{F}_{2}$ segregation for flower color and seedcoat pattern. Selection was made for plants with seeds having either bipunctata or virgarcus pattern. True-breeding selections were developed by the usual progeny testing routine described above. The result was the development of the genetic stocks: 'bipunctata $\mathrm{BC}_{3}$ 5-593' (Fig. 1) and 'virgarcus $\mathrm{BC}_{3} 5-593$ (Fig. 2).

A cross 'bipunctata $\mathrm{BC}_{3}$ 5-593' $\mathrm{x}$ 'virgarcus $\mathrm{BC}_{3}$ 5-593' was made and the $\mathrm{F}_{2}$ was planted in the field in 1995. Data were taken on the $\mathrm{F}_{2}$ segregation for seedcoat pattern.

\section{Results and Discussion}

For the crosses 'bipunctata $\mathrm{BC}_{1}-\mathrm{F}_{3} 5-593$ ' $\times 5-593$ and 'bipunctata $\mathrm{BC}_{2}-\mathrm{F}_{3} 5-593$ ' $\times$ 5-593, the $\mathrm{F}_{2}$ populations segregated for a good fit to a 12:3:1 ratio for three classes: 1 ) the combined totally colored, expansa (Fig. 3), and ambigua (Fig. 4) classes; 2) the virgarcus class; and 3) the bipunctata class (Table 2). All the genetic variation can be accounted for with only two genes segregating, viz., $z$ and bip (Table 2). Those results confirm the findings of Schreiber (1940). He also found that a single recessive gene converts virgarcus into bipunctata. Lamprecht (1940) interpreted his results to support the necessity of two recessive genes acting jointly to convert virgarcus to bipunctata (Table 1). Because Lamprecht (1940), Schreiber(1940), and I all derived our bipunctata stocks from the same source ('Incomparable'), it is probable that all have the same genotype. In Schreiber's (1940) material the heterozygote $t z$ Bip/bip produced weak virgarcus, but no distinctive phenotype for the heterozygote was observed (Table 2).

The above data (Table 2) also support the hypothesis of Schreiber (1940) that $t Z$ gives expansa and $t Z / z$ gives ambigua. It is my hypothesis that there is also a recessive gene (identity unknown) from 'Early Wax' that converts expansa to totally colored and that 5-593 has the dominant allele at that locus that maintains expansa (M.J. Bassett, unpublished data). The boundary between the expansa class and the ambigua class is very difficult to establish; hence, the classes were combined (Table 2). The ambigua class combines the classes maximus, major, and minor of Lamprecht (1940). The existence of Lamprecht's (1940) genes diffundere and expandere is a highly speculative hypothesis for which no adequate experimental data was ever provided for support. On the other hand, it was one of Schreiber's (1940) great contributions to fully substantiate the hypothesis that $t$ $Z / z$ produces the hypervariable ambigua phenotype.
In a previous commentary on the work of Lamprecht (1940) I stated that it was highly likely that Lamprecht's genes Arc, Diff, and Exp were nonexistent (Bassett, 1995). Unexpected field results from 1995 have demonstrated that there may be a gene (possibly not at either $Z$ or $L$ ) that can convert virgarcus into a weak virgarcus that is similar in appearance to the arcus illustrations of Lamprecht (1940) (M.J. Bassett, unpublished data). In light of those developments and the beginning of work with the 'Early Giant' variety with the virgata pattern of partly colored seedcoats it may be that the Arc gene can be recovered and verified.

The cross 'bipunctata $\mathrm{BC}_{3}$ 5-593' $x$ 'virgarcus $\mathrm{BC}_{3}$ 5-593' segregated in the $\mathrm{F}_{2}$ only for the parental classes, and the observed segregation fit a 3:1 ratio for virgarcus to bipunctata, respectively (Table 3). There was no distinctive phenotype for the heterozygote Bip/bip. It is my hypothesis that such distinctive heterozygote phenotypes may occur only when unrelated lines are crossed. When highly related $\left(\mathrm{BC}_{3}\right)$ lines are crossed, the heterozygote loses its distinctiveness.

From all the evidence provided above, it can be concluded that 1) 5-593 must have the genotype $T Z$ Bip, 2) that the genotype of 'bipunctata $\mathrm{BC}_{3} 5-593$ ' is $t z$ bip, and 3) that the genotype of 'virgarcus' $\mathrm{BC}_{3} 5-593$ is $t z$ Bip.

Table 3. Segregation for partly colored seedcoat patterns and genotypes among $\mathrm{F}_{2}$ progeny from the cross 'bipunctata $\mathrm{BC}_{3} 5-593$ ' $(t z$ bip $) \mathrm{x}$ 'virgarcus $\mathrm{BC}_{3}$ 5-593' ( $t$ z Bip).

\begin{tabular}{lcccc}
\hline \multicolumn{2}{c}{ Seedcoat pattern classes } & & \\
\cline { 1 - 1 } Virgarcus & Bipunctata & $\chi^{2}$ & \\
$t z$ Bip/- & $t z$ bip & $3: 1$ & $P$ \\
\hline 342 & 122 & 0.414 & 0.52 \\
\hline
\end{tabular}

\section{Literature Cited}

Bassett, M.J. 1994. The genotype for seedcoat color of breeding line 5593. Annu. Rpt. Bean Improv. Coop. 37:244-245.

Bassett, M.J. 1995. Translation (German to English) of the 1940 papers by Lamprecht and Schreiber on partly colored seeds and a critical review. Annu. Rpt. Bean Improv. Coop. 38:11-12.

Bassett, M.J. and Blom. 1991. A new genotype for white seed coat discovered in 'Early Wax' snap bean. J. Amer. Soc. Hort. Sci. 116:131136.

Lamprecht, H. 1940. Zur Genetik von Phaseolus vulgaris. XVI. Weitere Beiträge zur Vererbung der Teilfarbigkeit. Hereditas 26:277-291.

Leakey, C.L.A. 1988. Genotypic and phenotypic markers in common bean, p. 245-327. In: P. Gepts (ed.). Genetic resources of Phaseolus beans. Kluwer Academic Press, Boston.

Schreiber, F. 1940. Die Genetik der Teilfarbung der Bohnensamen (Phaseolus vulgaris). Zeitschr. Ind. Abst. Vererbungsl. 78:59-114. 